\title{
Single motherhood and marasmus among under-five children in Sub-Saharan Africa: a regional analysis of prevalence and correlates \\ Emmanuel O. Olamijuwon ${ }^{1}$, Clifford O. Odimegwu' ${ }^{1}$, Jeremy Gumbo ${ }^{1,2 a}$, and Vesper H. Chisumpa ${ }^{1,3}$
}

\author{
${ }^{1}$ Demography and Population Studies Programme, Schools of Public Health and Social Sciences, \\ University of the Witwatersrand, Johannesburg, South Africa. \\ ${ }^{2}$ Chris Hani Baragwanath Hospital, Johannesburg, South Africa. \\ ${ }^{3}$ Department of Population Studies, University of Zambia, Lusaka, Zambia. \\ e.olamijuwon@gmail.com
}

\begin{abstract}
Despite efforts aimed at improving child health status globally, marasmus remains a health burden in sub-Sahara Africa (SSA) and an important risk factor for illnesses and death, especially among young children. Using pooled data from the latest (20I0-20I4) demographic and health surveys of 2I-SSA countries, we examined the relationship between single motherhood and marasmus among under-fives in SSA. Multivariate logistic regression was fitted on a representative sample of 59,013 under-fives who were either marasmic or physically healthy. Contrary to some studies, we found no evidence that single-motherhood was associated with the risk of marasmus in SSA and its sub-regions regions. Results from the regression analysis revealed that the risk of marasmus was lower for under-fives of single mothers in West Africa (OR=0.72 Cl:0.508-I.0I6), East Africa (OR=0.55 Cl:0.230-I.299), Central Africa $(\mathrm{OR}=0.88 \mathrm{Cl}: 0.522-\mathrm{I} .487)$ and SSA (OR=0.87 Cl:0.699-I.070) but higher in Southern Africa $(\mathrm{OR}=\mathrm{I} .32 \mathrm{Cl}: 0.899-\mathrm{I} .946)$ all compared to under-fives of married mothers.
\end{abstract}

Keywords: single motherhood; under-five; marasmus; malnutrition; sub-Sahara Africa

\section{Introduction}

Despite efforts aimed at improving child health status globally, marasmus a form of protein-energymalnutrition (PEM) remains a significant health burden in developing countries and a major risk factor for illnesses and death especially among young children (Müller \& Krawinkel, 2005). Globally, an estimated 6.6 million children under age five years are reported to die each year implying about 18000 under-five deaths each day (UNICEF, WHO, World Bank, UN-DESA Population Division, 20I3). Of these deaths, the highest is said to be occurring in developing countries owing to conditions that could be prevented with access to simple and affordable interventions such as quality feeding, adequate medical and nursing intervention at birth (Faruque et al., 2008; WHO, 2006).

Often characterized by a lack of nearly all nutrients, particularly protein and calories, PEM is evident in severe weight loss, thin and papery skin that is sometimes darker than normal, pronounced hair loss, a pinched facial expression and extended periods of apathy (Bain et al., 20I3; WHO, 2006). This form of malnutrition, however, has several http://aps.journals.ac.za consequences on under-fives and has also been recognized to influence health and achievement throughout over an individual's life course, and result in a vicious circle of poverty (Müller \& Krawinkel, 2005). This is because, its effects on under-fives if not given proper attention are detrimental to growth, development. In the long run, it can hamper economic and social development as children with low intellectual quotients are less likely to be able to offer the best of mental abilities expected of them (Blössner et al., 2005).

It has also been identified to increase a child's susceptibility to a variety of infections, a direct cause of about 300,000 deaths per year and is indirectly responsible for about half of all deaths among underfives (Black, Morris, \& Bryce, 2003; Müller \& Krawinkel, 2005). It is also associated with a number of co-morbidities such as lower respiratory tract infections including tuberculosis, diarrhea diseases, malaria and anemia all of which may prolong resulting in death among affected children (Ejaz \& Latif, 2010; Ubesie, Ibeziako, Ndiokwelu, Uzoka, \& Nwafor, 2012). 
As gender roles become alike, women tend to have gained a high occupational and economic status which to an extent positions them at a disadvantage in their local marriage markets due to the stereotypic beliefs about single women of high economic status (Alam, Mondol, Tapan, \& Rahman, 2008; Dykstra \& Poortman, 20l0; Ntoimo \& Isiugo-Abanihe, 20l4). Earlier studies on non-marital childbearing have also underscored the adverse maternal and child health outcomes associated with being a single mother. This is because never married females who find themselves in this situation are often neglected, and uncared for. They are also likely to be anemic, malnourished during pregnancy and suffer severe complications because society and family believe that they are the sole cause of their adversity (Ikamari, 2005).

While early studies of child health have focused on country differences in relation to other forms of malnutrition such as stunting, wasting and underweight, very little is known about the association between single motherhood and marasmus across the regions of sub-Saharan Africa. Given that the effects of poverty, family structure and instability appear to be particularly detrimental for young children and endure through adulthood, we examine the association between single motherhood and marasmus in sub-Saharan Africa. An awareness of this relationship may contribute to public understanding as well as policy interventions towards addressing an underlying factor that may help reduce the prevalence of marasmus and under-five mortality from severe malnutrition (marasmus) in sub-Saharan Africa.

\section{LITERATURE REVIEW AND THEORETICAL FRAMEWORK}

Malnutrition is said to be a gross imbalance/overabundance of certain nutrients or its insufficiency in a diet thereby causing health problems (Dimosthenopoulos, 2010). Although some studies have documented the association between singlemotherhood and other aspects of malnutrition such as stunting, underweight and overweight, little or none is known on the single-motherhood association with marasmus globally as well as in sub-Sahara Africa.

Using data from the National Health Interview Survey 200I-2007, Blackwell found that children in single-parent families were more likely to have at least one chronic condition than children from other family types although the gender of the single-parent was not ascertained (Blackwell, 20I0). Bramlett and Blumber using the 2003 National Survey on Children's Health also found that children living in step or single-mother families had poorer health than 3357 children living with two biological parents, even adjusting for demographic differences (Bramlett and Blumber, 2007). A longitudinal study, using U.S. data from the fragile families and child well-being study also found that children living with a mother who recently dissolved a union or who had been living without a partner for at least 2 years are at an increased risk of gaining excessive weight compared with those in stable married two-parent families (Schmeer, 20I2). In addition, children living with single mothers who entered a new union had significantly healthier weight/height trajectories than those whose mothers remained single or who recently became single (Schmeer, 20I2).

In Latin America and the Caribbean, Fernald and Neufeld controlling for maternal characteristics and other standard controls found that both single motherhood and household size increased the risk of stunting, but marital status was found not to play any significant role in the risk of overweight (Fernald and Neufeld, 2007). A study of Jamaica's under-five malnutrition also found that children living in singleparent households as opposed to residing in a married couple household are at a greater risk of stunting (Bronte-Tinkew and Dejong, 2004)

In sub-Saharan Africa, available evidence has documented the relationship between marital status and under five's health and nutritional status. For instance, a study of I I sub-Saharan African countries, found that children of single mothers were more likely to die before five years of age (Clark, and Hamplová, 2013). Emerging perspectives on the relationship between single motherhood and underfive nutritional status also suggest that child wellbeing is closely linked to economic resources available in each family characteristics. For instance, Victora et al. (2003) showed that under-five malnutrition and health is primarily associated with inequalities in financial and material resources between households. This is likely because the economic advantage of children of married mothers is dependent on if the parents are gainfully employed and optimally committed to the child's mental, physical and social well-being which is expressed in a substantial cash contribution to children's nutrition and health care (Dearden, et al. 20l3). However, economic deprivation of single mothers may be attenuated by kin support (Gibson and Mace 2005; McGadney-Douglass, et al., 2005). From a socialization model point of view, Ntoimo and Odimegwu also argued that children of single mothers in sub-Saharan Africa are unlikely to have many health disadvantages if the mother is not young, works from home, have older children and has a form of support from her kin (Ntoimo and Odimegwu, 2014). A study in Uganda also found that 
children of married or cohabiting mothers were more likely to be marasmic, stunted and also underweight although no significant association was observed (Habaasa, 2015).

Given that the relationship between single motherhood remains unexplored, we used the framework by Mosley and Chen (1984) Framework for studying child survival in developing countries to examine this relationship. Mosley and Chen (1984) proposed that social and economic factors influence child's health through proximal or biological factors. Based on this framework, this study explores the interrelationship between single-motherhood (socioeconomic characteristics) and the risk of marasmus among under-fives in sub-Saharan Africa (SSA). The distal variable emphasized in this study include mother, child and household characteristics all of which are perceived to influence the risk of marasmus through the proximal variables (environmental characteristics).

\section{DATA AND METHODS}

We used secondary data from the latest (20I0-20I4) demographic and health surveys (DHS) of 2I-subSaharan African countries. These data are entirely anonymous, and all personal, confidential and identifying information of respondents had been removed to protect the identity of the children and minimize the risk of any harm. The extracted data for each country were pooled on a regional basis using the regional classification of the African Union to allow for comparative analysis. Details of countries aggregated for each region including their DHS years as well as their sample sizes are presented in Table I below.

Table I: Study Population and Sample

\begin{tabular}{|c|c|c|c|c|c|}
\hline Country/Region & DHS Year & $\begin{array}{c}\text { Under-five } \\
\text { Sample }\end{array}$ & Country/Region & DHS Year & $\begin{array}{l}\text { Under-five } \\
\text { Sample }\end{array}$ \\
\hline
\end{tabular}

\section{WEST AFRICA}

Burkina Faso

Benin

Mali

Nigeria

Sierra Leone

Senegal

TOTAL

\section{CENTRAL AFRICA}

Burundi
Cameroon
Congo Republic
Congo Brazzaville
Gabon

TOTAL

$\begin{array}{cc}2010 & 2030(15.5 \%) \\ 2011-12 & 1857(5.6 \%) \\ 2012-13 & 1139(9.7 \%) \\ 2013 & 4816(20.8 \%) \\ 2013 & 4816(20.8 \%) \\ 2010-11 & 1972(16.2 \%) \\ & 12825(14.6 \%)\end{array}$

\section{EAST AFRICA}

$\begin{array}{lcc}\text { Ethiopia } & 201 \mathrm{I} & 2452(10.1 \%) \\ \text { Kenya } & 2014 & 1670(4.6 \%) \\ \text { Comoros } & 2012 & 784(8.6 \%) \\ \text { Rwanda } & 2010-1 \mathrm{I} & 1857(0.2 \%) \\ \text { Uganda } & 2011 & 1261(8.4 \%) \\ \text { TOTAL } & & 9404(6.8 \%)\end{array}$

\section{SOUTHERN AFRICA}

$\begin{array}{lcc}\text { Malawi } & 2010 & 3307(11.3 \%) \\ \text { Mozambique } & 2011 & 1957(24.8 \%) \\ \text { Namibia } & 2013 & 1067(2.8 \%) \\ \text { Zambia } & 2013-14 & 2129(6.7 \%) \\ \text { Zimbabwe } & 2010-11 & 1161(13.0 \%)\end{array}$

TOTAL
The datasets contain anthropometric data including height and weight of children under-five years in all the selected households. Children under two years were measured lying down on the board (recumbent length), and standing height was measured for all other children.

\section{Study Population and Sample Size}

The study population comprised of under-fives aged 6-59 months with a representative sample of 108394 http://aps.journals.ac.za under-fives in sub-Saharan Africa (SSA) with 43,03I in West Africa (WA), 22,067 under-fives in East Africa (EA), 18,309 under-fives in Central Africa (CA) and 24,987 under-fives in Southern Africa (SA). Our regression analysis was however modeled on a representative sample of 59,013 under-fives excluding those with other forms of malnutrition. We limited our population to under-fives aged 6-59 months because PEM manifests only after six months (Müller \& Krawinkel, 2005). Details of how the study 
sample was selected are presented in Figure I. From Table 2, it is also evident that about $4 \%$ of underfives in SSA were born to never-married single mothers with regional differences ranging from almost $7 \%$ in SA to about 2\% in WA. The majority of the children were also born to women who are adults (age $25-34$ years), while only about $2 \%$ were born to women who were 45 years or older. In WA, more than half $(61 \%)$ of the children were born to women with no education compared to other regions where almost two-in-three children were born to women with some formal education. The percentage of children born to women with higher education is highest in the EA region (about 4\%) and lowest in SA (2\%). Similarly, the majority of the children (about 61\% in SSA) were also born to mothers who are currently employed and a similar pattern could also be observed across the regions with variations as high as about $71 \%$ in $C A$ to less than $55 \%$ in EA. Across wealth status, slightly more than one-third of the children in SSA and across the regions reside in rich households, and more than three-quarters (85\%) reside in male-headed households. Consequently, the under-fives by sex ratio showed nearly similar sex ratios across the regions with an almost equal number of boys and girls aged 6-59 months in SSA and even in WA, CA and SA except in EA where there are about 102 boys per 100 girls.

Figure I: Study Sample Selection Procedure

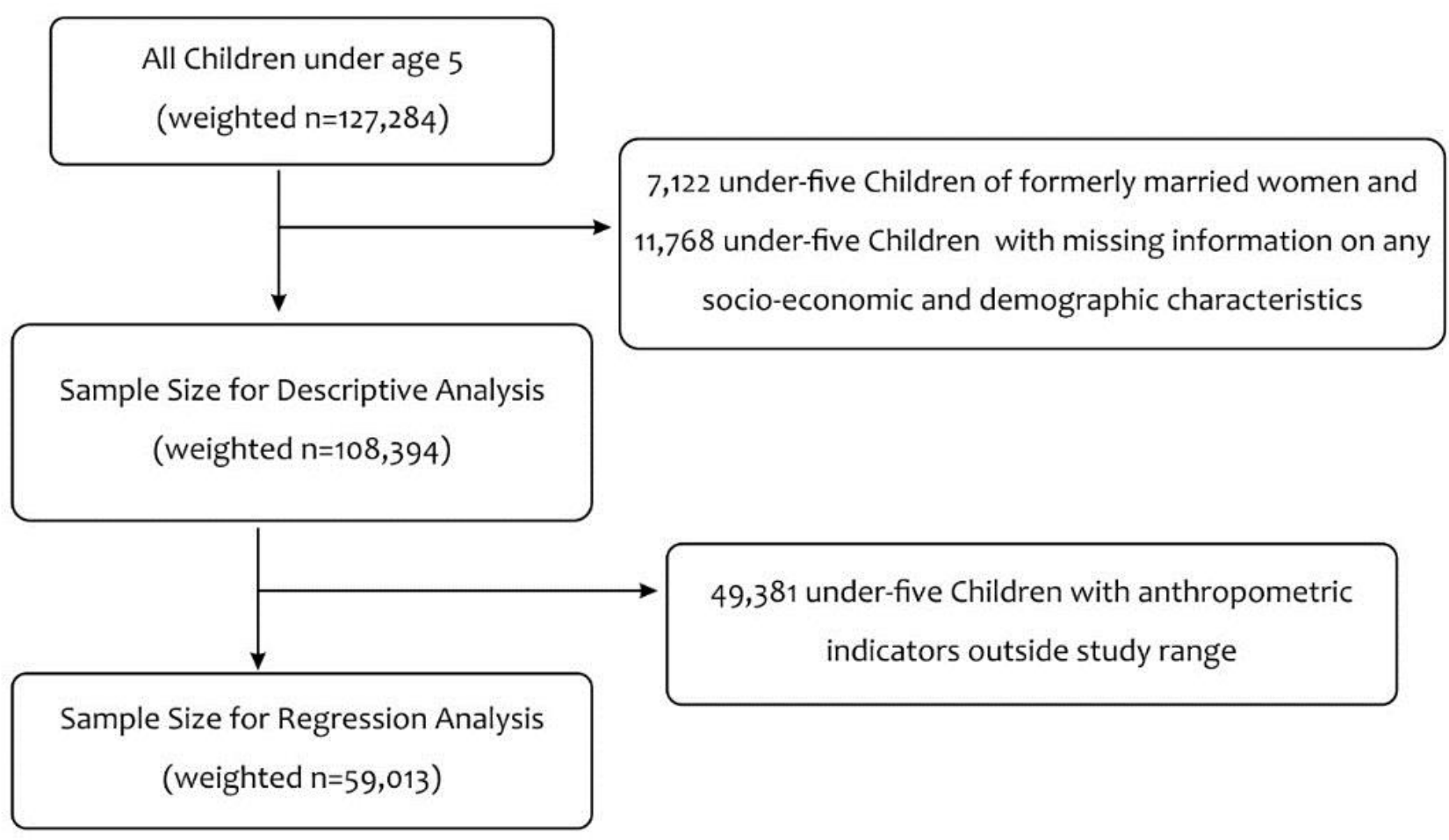

Table 2: Descriptive Profile (in percentages) of Under-Fives in sub Saharan Africa and sub-regions

\begin{tabular}{|c|c|c|c|c|c|}
\hline $\begin{array}{l}\text { Socio-Demographic } \\
\text { Characteristics }\end{array}$ & $\begin{array}{l}\text { West Africa } \\
(n=4303 \mathrm{I})\end{array}$ & $\begin{array}{l}\text { East Africa } \\
(n=22067)\end{array}$ & $\begin{array}{l}\text { Central Africa } \\
(n=18309)\end{array}$ & $\begin{array}{l}\text { Southern Africa } \\
\qquad(n=24987)\end{array}$ & $\begin{array}{c}\text { sub-Sahara Africa } \\
(\mathrm{n}=108394)\end{array}$ \\
\hline
\end{tabular}

\section{Mother's Marital Status}

Never Married

Currently Married

Mother's Age

$15-24$ Years

$25-34$ Years

$35-44$ Years

$45+$ Years
1.9

98.1

23.5

51

22.9

2.6
3.4

96.6

23.2

52.9

21.7

2.2
6.1

93.9

26.5

50.5

21.2

I.8
6.9

93.1

31

46.9

20.1

2
4. I

95.9

25.7

50.4

21.7 


\section{Mother's BMI}

Underweight

9.1

12.6

9.6

7.2

Moderate BMI

69.1

67.9

66.6

72.3

69.2

Overweight

16.2

14.2

16.4

15.4

15.6

Obese

5.6

5.3

7.4

5.1

5.7

Mother's Education

No Education

61.4

38

45.3

23.1

18.3

52.2

27.4

12.8

Secondary

Higher

17.9

3.4

3.9

35.2

2.6

46.3

53.7

28.6

71.4

44.1

20.1

35.8

43.7

19.9

36.4

14.2

82.4

89.5

3.4

Other Females

Place of Residence

Urban

4.2

20.4

32.2

79.6

9.9

84

6.1

40.8

59.2

Religious Affiliation

No Religion

I. I

Muslim

62.5

Others

Child's Sex

Male

Female

Child's Size at Birth

\section{Large}

Average

Small
1.2

\section{4}

50.2

49.8

50.8

49.2

38

47.9

14.1

32.7

46.3

21
0.9

72.7

25.2

\section{3}

87.5

8.1

2.1

49.5

50.5
50.2

34.8

15
2.1

52.6

47.4

45.9

20.5

34.6

13.3

10.1

$80 \quad 85$

6.7

4.9

30.4

28.7

69.6

71.3

3.9

86.9

62.5

7.7

33.1

1.5

2.5

49.7

50.1

50.3

49.9

40.2

39.5

47.8

45.3

12

15.2
Variable Description

Outcome Variable: Under-five marasmic status was dichotomized into marasmic and non-marasmic. This nutritional indicator for children under-five years were calculated using growth standards published by the World Health Organization in 2006. Marasmic under-fives were defined as having a weight-forheight Z-score less than -3 standard deviations ( $\mathrm{WHZ}$ $<-3$ SD) for all under-fives (6-59 months). Nonmarasmic was also categorized as having no physical signs of malnutrition such as wasting (low weight for height), stunting (low height for age), overweight (high weight for height) and underweight (low weight http://aps.journals.ac.za for age). These growth standards were generated through data collected in the WHO Multicentre Growth Reference Study and expressed in standard deviation units (de Onis et al., 2004).

Main Predictor Variable: Marital status was categorized as 'single mother' for women who reported being single and never married and 'married mother' for women who reported to be cohabiting/married. Under-fives of formerly married women were excluded from our study because the category combines divorced or separated women as well as widowed. Similarly, because of strong family 
ties, widowed formerly married women are likely to get support from their relatives and sometimes from those of their deceased spouse as well as from religious and social organizations (Madhavan \& Townsend, 2007; Takyi \& Gyimah, 2007).

Covariates: Mother's age was categorized using 10 years interval with ages I5-24 categorized as (I), '2534 ' categorized as (2), 35-44 years categorized into (3) and $45-49$ years categorized as (4). Women's body mass index (BMI) was also assessed by measuring women's height and weight. Women with $\mathrm{BMI}<18.5$ were classified as 'underweight,' I8.5-25 were classified as 'healthy BMI,' 25-30 were classified as overweight, and 30 and above was operationalized and classified as 'obese.' Educational attainment for child's mother was assessed from the question that asked women for their highest level of education. Women with no formal education were coded and categorized as (0), and women with primary education were coded as (I) those with secondary education were coded as (2), and those with more than secondary education were coded as (3) and classified as higher education. Employment status for women was assessed from the question that asked women about their recent economic activity. Women who are currently unemployed, inactive or retired are classified as 'unemployed' and coded as (0) while those who are employed are coded as (I). The religious affiliation of women was also assessed from the question that asked for the religion each woman practices. Women with no religious affiliation were coded (0) while those who were Pentecostal, Methodist, Anglican, Catholic or Zion were classified as 'Christians' (I). Women who also reported being 'Muslims' were code (2) and those in traditional religion and other religion were classified as 'others' (3). Household wealth was assessed from the wealth index variable which encompasses some indicators like household properties, access to water and sanitation services, income and others. From the index, women in poor or poorest households were then coded ( 0 ) and classified as poor, while those who reported 'average' were coded (I) and those reported to be living in richer or richest household were categorized as living in 'rich' household and coded (I). Being a variable with binary options, place of residence was coded $(\mathrm{I})$ for women in rural place of residence and (2) for women residing in the urban place of residence. Sex of household head was derived from women's relationship to the house head as well as the question that asked for the sex of the household head. Women who reported to be household heads were categorized as $(0)$ while those who reported being under the headship of a male were coded $(\mathrm{I})$ and those who reported being under the headship of another female like mother, sister or aunt were coded (2). Birth type for under-fives was also dichotomized and categorized as (I) for underfives whose mother reported to be a singleton and (2) for those who were multiple births such as twins, triplets or more. Size at birth for under-fives was assessed from the survey by asking women for the child's size at birth. Among children that were weighed at birth, a follow-up question on the weight of the child (in kilograms) at birth was asked. These questions were then categorized into small at birth (I), average (2) and large (3).

\section{Analytical Approach}

Frequency distributions, line graphs, and bar charts were used to describe the levels and patterns of marasmus across the regions. To ascertain the association and risk of an under-five being marasmic relative to the mother's marital status, we fitted stepwisely, a binomial logistic regression model.

Models for each region were estimated to examine the association between single motherhood and under-five marasmus while controlling for other important characteristics. Data management and analysis were done using Stata software 14 and interpretation of results were done using odds ratios (OR) with $O R>I$ implying higher risk, $O R<1$ implying lower risk and $O R=I$ implying no risk difference. The level of significance was set at 0.05 , and a confidence interval $(\mathrm{Cl})$ of $95 \%$ was used. Data and variables were weighted to correct for survey design sampling errors. Tests for goodness-of-fit and specification error showed that the model fits reasonably to the data.

\section{RESULTS \\ Levels and Patterns of Marasmus among children under-five years in SSA \\ Results of the levels of marasmus in SSA and sub- regions presented in Figure 2 below showed that about $4 \%$ of under-fives in SSA are marasmic with regional differences ranging from almost $7 \%$ in WA to less than $2 \%$ in other regions.}


Figure 2: Levels of Marasmus among Under-Fives in sub-Saharan Africa

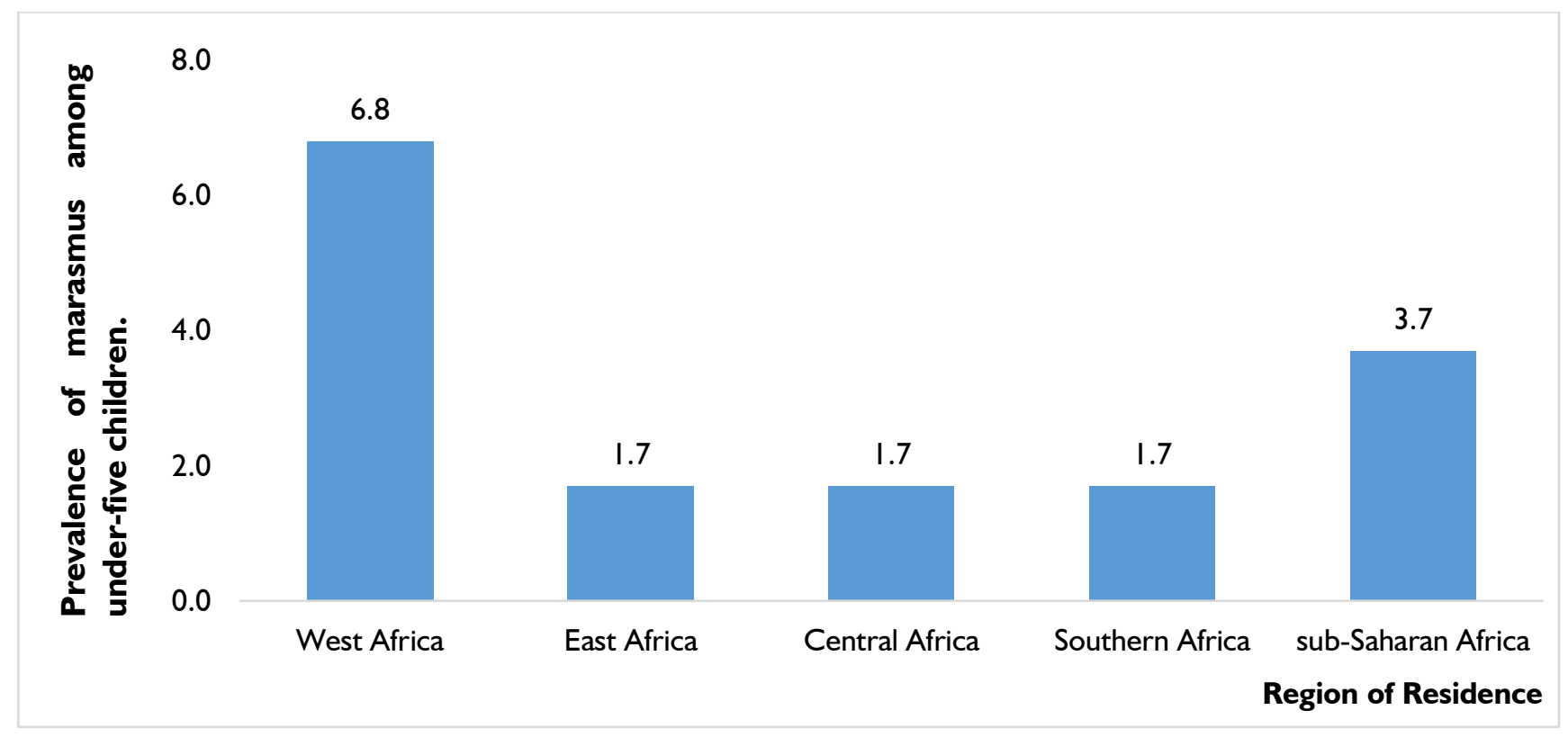

Results of the prevalence of marasmus relative to mother's marital status as evident in Figure 3 below showed that the prevalence of marasmus was lower among under-five children of single mothers in WA $(5 \%)$, EA ( $1 \%)$ and CA (2\%) but higher among under-fives of single mothers in the SA region (2\%). From the Table 3 below, results also suggest that marasmus is most prevalent among young mothers (ages 15-24 years) and lowest among women aged 45 years or more. We observed that under-five children of women with no education had a higher prevalence of marasmus (WA-8\%, EA-3\%, CA- $2 \%, \mathrm{SA}-2 \%$, SSA-6\%) and this pattern reduces as level of education increases in all the regions and sub-Saharan
Africa except for East and Southern Africa. This pattern was also observed across levels of household wealth with poor households having the highest prevalence of under-five children with marasmus with a decline as wealth status improves. Unemployed women also had a higher prevalence of marasmus in SSA as well as in the WA (7\%) and EA (2\%) regions. Surprisingly, more of the children born to employed mothers were marasmic in Central (2\%) and Southern (2\%) African regions. Consequently, SSA and across the regions, more boys (WA-7\%, EA-2\%, CA-2\%, SA-2\%, SSA-4\%) were marasmic than girls. 
Figure 3: Bivariate Pattern of Marasmus among under-fives by Mother's Marital Status

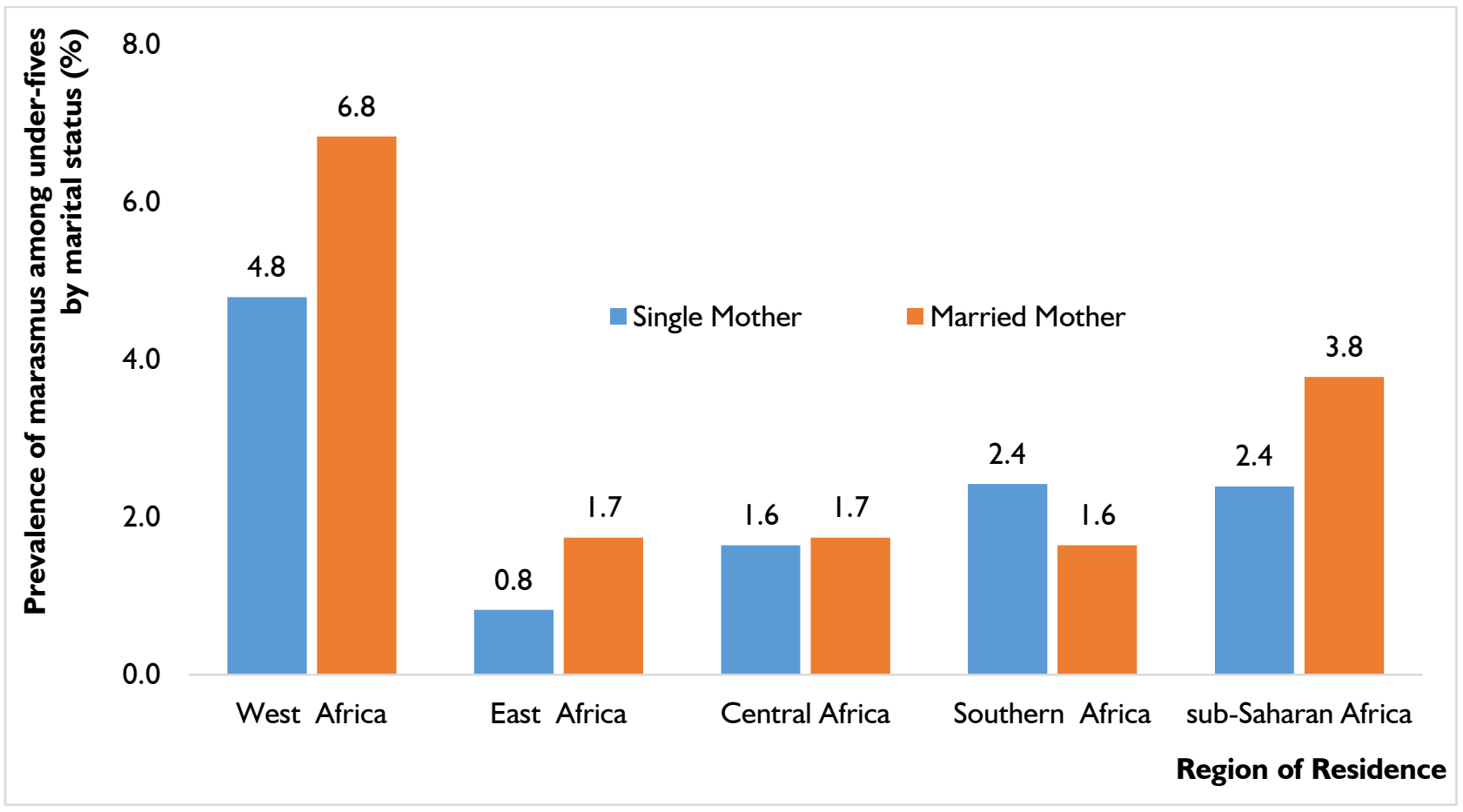

Table 3: Prevalence (in \%) of Marasmus among Under-fives by Selected Characteristics

\begin{tabular}{|c|c|c|c|c|c|}
\hline $\begin{array}{l}\text { Socio-Demographic } \\
\text { Characteristics }\end{array}$ & $\begin{array}{l}\text { West Africa } \\
(n=43,03 I)\end{array}$ & $\begin{array}{l}\text { East Africa } \\
(n=22,067)\end{array}$ & $\begin{array}{l}\text { Central Africa } \\
(n=18,309)\end{array}$ & $\begin{array}{l}\text { Southern Africa } \\
\qquad(n=24,987)\end{array}$ & $\begin{array}{c}\text { sub-Sahara } \\
\text { Africa } \\
(\mathrm{n}=108,394)\end{array}$ \\
\hline Mother's Age & **** & **** & 抽 & **** & **** \\
\hline $15-24$ Years & 7.6 & 1.8 & 1.9 & 1.8 & 3.9 \\
\hline $25-34$ Years & 6.6 & 1.7 & 1.8 & 1.5 & 3.6 \\
\hline $35-44$ Years & 6.4 & 1.8 & 1.5 & 1.9 & 3.7 \\
\hline $45+$ Years & 6 & 0.8 & 1.3 & 2 & 3.5 \\
\hline Mother's BMI & **** & **** & **** & **** & **** \\
\hline Underweight & 7.2 & 3.2 & 2.7 & 1.9 & 4.4 \\
\hline Moderate BMI & 7.1 & 1.6 & 1.9 & 1.9 & 3.9 \\
\hline Overweight & 6.5 & 1 & 1.1 & I.I & 3.3 \\
\hline Obese & 3.6 & 0.8 & 0.3 & 0.6 & 1.8 \\
\hline Mother's Education & **** & **** & **** & **** & **** \\
\hline No Education & 7.7 & 2.7 & 2.4 & 2.3 & 5.7 \\
\hline Primary & 5.5 & 1.2 & 1.8 & 1.8 & 2.4 \\
\hline Secondary & 5.4 & 0.8 & 1.3 & 1.1 & 2.5 \\
\hline Higher & 3.9 & 0.9 & 0.7 & 2 & 2.3 \\
\hline Employment Status & **** & $* * *$ & **** & **** & 㧊 \\
\hline Unemployed & 7.4 & 2.3 & 1.6 & 1.6 & 3.6 \\
\hline Employed & 6.5 & 1.2 & 1.8 & 1.8 & 3.8 \\
\hline
\end{tabular}


Table 4 Cont: Prevalence (in \%) of Marasmus among Under-fives by Selected Characteristics

\begin{tabular}{|c|c|c|c|c|c|}
\hline $\begin{array}{l}\text { Socio-Demographic } \\
\text { Characteristics }\end{array}$ & $\begin{array}{l}\text { West Africa } \\
(n=43,031)\end{array}$ & $\begin{array}{l}\text { East Africa } \\
(n=22,067)\end{array}$ & $\begin{array}{c}\text { Central Africa } \\
(n=18,309)\end{array}$ & $\begin{array}{l}\text { Southern Africa } \\
\quad(n=24,987)\end{array}$ & $\begin{array}{c}\text { sub-Sahara Africa } \\
\quad(n=108,394)\end{array}$ \\
\hline Household Wealth & **** & **** & **** & $* * *$ & **** \\
\hline Poor & 8.1 & 2.4 & 2.3 & 2.1 & 4.5 \\
\hline Average & 6.6 & 1.5 & 1.7 & 1.6 & 3.6 \\
\hline Rich & 5.4 & 1 & 1 & 1.2 & 2.9 \\
\hline Sex Household Head & 㧊 & **** & **** & 抽 & 㧊 \\
\hline Self & 4.8 & 2 & 2.2 & 1.7 & 2.6 \\
\hline Male & 7 & 1.7 & 1.7 & 1.6 & 3.9 \\
\hline Other Females & 4.6 & 1.4 & 1.4 & 2.4 & 2.8 \\
\hline Place of Residence & **** & **** & **** & **** & **** \\
\hline Urban & 6.7 & 1.2 & 0.9 & 1.6 & 3.5 \\
\hline Rural & 6.8 & 1.8 & 2.3 & 1.7 & 3.8 \\
\hline Religious Affiliation & **** & **** & **** & **** & **** \\
\hline No Religion & 4.7 & 1.5 & 2.3 & 1.3 & 2.3 \\
\hline Christian & 5 & 1.3 & 1.7 & 1.6 & 2.2 \\
\hline Muslim & 7.8 & 2.8 & 2.2 & 3.1 & 6.5 \\
\hline Others & 6.3 & 4.6 & 2.6 & 0.7 & 4.8 \\
\hline Child's Sex & **** & **** & **** & $* * *$ & **** \\
\hline Male & 7.3 & 2.1 & 2 & 1.9 & 4.1 \\
\hline Female & 6.3 & 1.3 & 1.5 & 1.4 & 3.3 \\
\hline Child's Size at Birth & **** & 㧊 & **** & 㧊 & 㧊 \\
\hline Large & 5.9 & 1.6 & 1.4 & 1.3 & 3.2 \\
\hline Average & 6.9 & 1.3 & 1.8 & 1.7 & 3.8 \\
\hline Small & 8.7 & 2.8 & 2.7 & 2.7 & 5.0 \\
\hline Succeeding Birth Spacing & 㧊 & **** & **** & 㧊 & 㧊 \\
\hline$<2$ Years & 5.2 & 2.0 & 1.0 & 1.1 & 2.9 \\
\hline 2 Years & 4.8 & I.I & 0.8 & 1.3 & 2.6 \\
\hline 3 Years & 6.4 & 1.4 & 0.7 & 1.2 & 3.3 \\
\hline $4+$ Years & 4.6 & 1.6 & 2.1 & 0.4 & 2.6 \\
\hline Last Birth & 7.6 & 1.8 & 2.2 & 1.9 & 4.2 \\
\hline
\end{tabular}

*** $-p<0.0 ; \neq \neq \neq-p>0.05$

\section{Relationship between Single Motherhood and Marasmus}

Results of the binomial regression analysis modeled across each region of sub-Saharan Africa are presented in Table 4 below. Although we found no statistically significant association between single motherhood and marasmus across the regions, results showed that under-five children of single mothers in WA [OR:0.72, Cl:0.5I-I.02], EA [OR:0.55, Cl:0.23-I.30], CA [OR:0.88, Cl:0.52-I.49] and SSA [OR:0.87, Cl:0.70-I.07] in general had a lower risk of marasmus compared to children of married mothers. Other predictor variables which were significantly associated with the risk of marasmus in most of the regions are mother's education, employment status, household wealth, place of residence, child's sex and religious affiliation.
For instance, across levels of education, we found that the risk of marasmus is lower among children of single mothers with secondary education in SSA [OR:0.54, Cl:0.48-0.60] and sub-regions including WA [OR:0.74, Cl:0.65-0.84], EA [OR:0.39, Cl:0.240.62], CA [OR:0.64, Cl:0.45-0.90] and SA [OR:0.38, $\mathrm{Cl}: 0.27-0.54]$ compared to children of women with no education and the relationships were statistically significant while controlling for other predictor variables. Surprisingly, under-five children in rural place of residence had a lower risk of marasmus in WA [OR:0.64, Cl:0.57-0.7I] (36\%), SA [OR:0.63, $\mathrm{Cl}: 0.48-0.84]$ and SSA [OR:0.70, Cl:0.64-0.76] but about two-times-higher risk in the $\mathrm{CA}$ region [OR:2.40, Cl:I.72-3.36] and the relationships were statistically significant. Additionally, under-fives in poor households were about two times at risk of marasmus in SSA and majority of the sub-regions 
compared to those in rich households and the relationships were also statistically significant adjusting for other variables in the models. Female under-five children in SSA [OR:0.7I, Cl:0.66-0.76] and across the sub-regions also had a significantly lower risk of marasmus compared to males. In SSA
[OR:0.39, Cl:0.36-0.42] and most of the sub-regions including WA [OR:0.65, Cl:0.59-0.72], EA [OR:0.60, $\mathrm{Cl}: 0.48-0.76]$, and SA [OR:0.45, Cl:0.33-0.6I], we found that under-fives of women who are Christians had a lower risk of marasmus compared to children of women who were Muslims.

Table 5: Multivariate Binomial Logistic Regression Model controlling for Maternal, Household, Child and Environmental characteristics

\begin{tabular}{|c|c|c|c|c|c|}
\hline $\begin{array}{l}\text { Socio-economic } \\
\text { and Demographic } \\
\text { Characteristics }\end{array}$ & $\begin{array}{l}\text { West Africa } \\
(23,118)\end{array}$ & $\begin{array}{l}\text { East Africa } \\
(12,319)\end{array}$ & $\begin{array}{l}\text { Central Africa } \\
(10285)\end{array}$ & $\begin{array}{l}\text { Southern Africa } \\
\qquad(13290)\end{array}$ & $\begin{array}{l}\text { Sub-Sahara Africa } \\
\qquad \begin{array}{l}59012)\end{array}\end{array}$ \\
\hline \multicolumn{6}{|l|}{ Marital Status } \\
\hline Never Married & $0.72[0.5 \mathrm{I}-\mathrm{I} .02]$ & $0.55[0.23-1.30]$ & $0.88[0.52-\mathrm{I} .49]$ & $1.32[0.90-1.95]$ & $0.87[0.70-1.07]$ \\
\hline \multicolumn{6}{|c|}{ Mother's Education } \\
\hline No education & Ref & Ref & Ref & Ref & Ref \\
\hline Primary & $0.68 *[0.60-0.77]$ & $0.59 *[0.46-0.76]$ & $0.78[0.59-1.04]$ & $0.78 *[0.60-1.00]$ & $0.54 *[0.50-0.59]$ \\
\hline Secondary & $0.74 *[0.65-0.84]$ & $0.39 *[0.24-0.62]$ & $0.64 *[0.45-0.90]$ & $0.38 *[0.27-0.54]$ & $0.54 *[0.48-0.60]$ \\
\hline Higher & $0.53 *[0.40-0.7 I]$ & $0.55[0.25-1.19]$ & $0.43[0.14-1.36]$ & $0.83[0.41-1.68]$ & $0.5 I *[0.40-0.65]$ \\
\hline \multicolumn{6}{|c|}{ Mother's Employment Status } \\
\hline Unemployed & Ref & Ref & Ref & Ref & Ref \\
\hline $\begin{array}{l}\text { Employed } \\
\text { Household Wealt }\end{array}$ & \multicolumn{4}{|c|}{ Household Wealth } & $1.16 *[1.08-1.24]$ \\
\hline Poor & $2.25 *[2.00-2.54]$ & $2.16 *[1.60-2.92]$ & $1.44 *[1.03-2.00]$ & $2.28 *[1.66-3.12]$ & $1.96 *[1.78-2.16]$ \\
\hline Average & $1.56 *[1.37-1.78]$ & $1.47 *[1.03-2.10]$ & $\mathrm{I} .27[0.88-\mathrm{I} .83]$ & $1.53 *[1.10-2.14]$ & $1.41 *[1.26-1.56]$ \\
\hline Rich & Ref & Ref & Ref & Ref & Ref \\
\hline \multicolumn{6}{|c|}{ Mother's Religious Affiliation } \\
\hline No Religion & $0.50 *[0.32-0.77]$ & $0.58[0.18-1.86]$ & I.23 [0.57-2.65] & $0.34 *[0.18-0.63]$ & $0.35 *[0.26-0.47]$ \\
\hline Christians & $0.65 *[0.59-0.72]$ & $0.60 *[0.48-0.76]$ & $0.94[0.63-\mathrm{I} .42]$ & $0.45 *[0.33-0.61]$ & $0.39 *[0.36-0.42]$ \\
\hline Muslims & Ref & Ref & Ref & Ref & Ref \\
\hline Others & $0.73 *[0.59-0.90]$ & $1.25[0.65-2.38]$ & $1.32[0.62-2.80]$ & $0.16 *[0.04-0.53]$ & $0.66 *[0.54-0.79]$ \\
\hline \multicolumn{6}{|c|}{ Place of Residence } \\
\hline Urban & Ref & Ref & Ref & Ref & Ref \\
\hline Rural & $0.64 *[0.57-0.7 I]$ & $0.88[0.63-1.24]$ & $2.40 *[1.72-3.36]$ & $0.63 *[0.48-0.84]$ & $0.70 *[0.64-0.76]$ \\
\hline \multicolumn{6}{|l|}{ Child's Sex } \\
\hline Male & Ref & Ref & Ref & Ref & Ref \\
\hline Female & $0.77 *[0.71-0.83]$ & $0.54 *[0.43-0.67]$ & $0.60 *[0.48-0.76]$ & $0.63 *[0.5 \mathrm{I}-0.76]$ & $0.7 \mid *[0.66-0.76]$ \\
\hline \multicolumn{6}{|c|}{ Child's Size at Birth } \\
\hline Large & $0.73 *[0.67-0.80]$ & $1.30 *[1.00-1.68]$ & $0.62 *[0.48-0.81]$ & $0.72 *[0.57-0.90]$ & $0.75 *[0.70-0.81]$ \\
\hline Average & Ref & Ref & Ref & Ref & Ref \\
\hline Small & $1.28 *[1.14-1.43]$ & $2.40 *[1.86-3.10]$ & $1.65 *[1.21-2.24]$ & $1.98 *[1.5 \mathrm{I}-2.60]$ & $1.35 *[1.23-1.47]$ \\
\hline \multicolumn{6}{|l|}{ Birth Type } \\
\hline Single Birth & Ref & Ref & Ref & Ref & Ref \\
\hline Multiple Births & $1.34 *[1.07-1.67]$ & $0.83[0.35-1.96]$ & $0.47[0.19-1.18]$ & I.72 [0.96-3.08] & $1.33 *[1.09-1.61]$ \\
\hline $\begin{array}{l}\text { Number of under- } \\
\text { fives in Household }\end{array}$ & 1.01 [0.98-1.04] & 1.11 [0.96-1.29] & $1.09[0.98-1.21]$ & $1.04[0.92-1.17]$ & $1.05 *[1.03-1.08]$ \\
\hline
\end{tabular}




\section{DISCUSSION OF FINDINGS}

Exploring the risk of marasmus in SSA, this study provides empirical evidence on the association between single-motherhood and the risk of marasmus among children under five years. With a prevalence rate of about $4 \%$, this study attests to the fact that marasmus is quite low among under-fives in sub-Saharan Africa although the highest prevalence can be observed in West Africa while the prevalence is very low in other regions.

Controlling for a number of women, child, and household socio-economic, environmental and demographic characteristics, we argued that children born to single mothers were at higher risk of marasmus compared to children of currently married women. This is based on the assumption that children of single mothers are likely to experience worse health outcomes because of the less care and support their mothers will have access to (Heiland \& Liu, 2006; Ntoimo \& Odimegwu, 20I4). Findings from this study, however, showed a counter-pattern as a lower risk of marasmus was observed among children of single mothers in most of the regions including sub-Saharan Africa except SA although no statistically significant associations were observed. The risk was lower for single-mothers most likely because of women empowerment economically, educationally or both which has been identified to be a contributing factor to the increase in single motherhood all over the world (lkamari, 2005; Ntoimo \& Isiugo-Abanihe, 20I4). Mostly wealthy or average wealthy women tend to remain single after a marital dissolution whereas the unemployed and uneducated women are likely to remarry or stay in a marriage even when the partner is unfaithful (Yount \& Carrera, 2006). Women in recent times are also becoming self-dependent, economic contributors and breadwinners many of whom utilize this singlehood status to build-up themselves, reach the peak of their career without allowing themselves to be limited by the society while also doing the best possible to support their children (Yount \& Carrera, 2006).

There are several strengths to our findings. The first is that the data for our study were collected from a well-defined geographical area using structured questionnaires and are representative of under-five children in sub-Saharan Africa. This has increased our chance of accurately estimating the risk of marasmus between those living with a single mother and those living with a married mother. The second is our relatively large sample size, which increases the statistical power to detect differences. The third is that we have examined an aspect of child malnutrition which has been sparsely explored in most previous studies enabling for a more holistic and rich literature on the relationship between single motherhood and under-five malnutrition in the context of the demographic transition and greater empowerment of women in the sub-Saharan Africa region.

There are, however, limitations to these findings. First, because the study is limited in its ability to determine the timing of each demographic event especially that of mother's marital history, it is slightly difficult to examine if the currently married women were once divorced, widowed or if the current partner is the biological father of the child. This would have been essential because in some cultures (such as Chokolo in Malawi, Ho Kenela in Lesotho, Luo tribe in Kenya, Ukungena in South Africa and among the Yorubas in Nigeria), women whose partners died are quickly provided with another partner who often is a sibling of the deceased in order to maintain 'balance' in the society (Ayodele, 20I4). As a result, only fewer household resources are likely to be directed towards the widow's child(ren) who are not biologically related to the new spouse while more resources are directed towards their own (new partner's) biological children (Clark \& Hamplová, 2013). The relative advantage of children in two-parent families with regards to well-being has also been associated more with stable unions, especially of two biological parents (Amato, 20l0).

\section{CONCLUSION AND RECOMMENDATIONS}

Conclusively, we found no evidence that singlemotherhood was associated with marasmus in subSaharan Africa and across its sub-regions. Its pattern also debunks the general perception of the negative child health outcome related to single-motherhood as no statistically significant risk of marasmus was observed among under-fives of never-married single mothers compared to those of married mothers.

Based on the findings of this study, it may, therefore, be important that continuous efforts be made to strengthen policies that seek to improve children's health status generally without neglecting women in marital unions. Such policies that may help address the problem of malnutrition from antenatal through to the child's first two years of life. Further studies using longitudinal data may also be essential taking into consideration the timing of marital dissolution and reformation as well as biological relationships in each family structure.

\section{CONFLICT OF INTEREST}

The authors declare that there is no conflict of interest regarding the publication of this paper. 


\section{ACKNOWLEDGEMENT}

The support of the DST-NRF Centre of Excellence in Human Development towards the research is hereby acknowledged. Opinions expressed and conclusions arrived at are those of the authors and not necessarily to be attributed to either the DST/NRF Centre of Excellence in Human Development

\section{REFERENCES}

Alam, R., Mondol, D.K., Tapan, K.R \& Rahman, S. 2008. "Effect of the working status of Bangladeshi women on age at marriage and fertility." Pakistan Journal of Social Sciences 5, (5): 493-497

Amato, P.R. 2010. "Research on Divorce: Continuing Trends and New Developments." Journal of Marriage and Family 72, (3): 650-666. https://doi.org/I0. I I I I/j. I 74I-3737.20I0.00723.x

Ayodele, J. O. 2014. Gender Victimization. SAGE Open, 4, (3) 2158244014544290.

Bain, L.E., Awah, P.K., Geraldine, N., Kindong, N. P., Siga, Y., Bernard, N \& Tanjeko, A.T. 2013. "Malnutrition in Sub-Saharan Africa: burden, causes and prospects." Pan African Medical Journal I5, (I).

Black, R.E., Morris, S.S \& Bryce, J. 2003 "Where and why are 10 million children dying every year?" The Lancet 36I, (9376): 2226-2234.

Blössner, M., De Onis, M., Prüss-Üstün, A., Campbell-Lendrum, D., Corvalán, C \& Woodward, A. 2005. "Quantifying the health impact at national and local levels." WHO, Geneva. Retrieved from http://www.who.int/entity/quantifying_ehimpacts/ publications/MalnutritionEBD 12.pdf?ua = I

Bramlett, M.D \& Blumberg, S.J., 2007. Family structure and children's physical and mental health. Health affairs, 26(2), pp.549-558.

Bronte-Tinkew, J \& Dejong, G. 2004. "Children's nutrition in Jamaica: do household structure and household economic resources matter?" Social Science \& Medicine, 58, (3): 499-5 I 4.

Clark, S \& Hamplová, D. 2013. "Single Motherhood and Child Mortality in Sub-Saharan Africa: A Life Course Perspective." Demography 50, (5): I52|1549. https://doi.org// 0.1007/s | 3524-0| 3-0220-6

Medical Association Journal 173, (3): 279-286. https://doi.org//0.1503/cmaj.050342

Ntoimo, L.F \& Odimegwu, C.O. 2014. "Health effects of single motherhood on children in subSaharan Africa: a cross-sectional study." BMC Public Health, I4, (I): I 145.

Ntoimo, L.F.C \& Isiugo-Abanihe, U. 2014. "Determinants of Singlehood: a retrospective account by older single women in Lagos, Nigeria." African Population Studies 27, (2): 386. de Onis, M., Garza, C., Victora, C.G., Onyango, A.W., Frongillo, E.A \& Martines, J. 2004. "The WHO Multicentre Growth Reference Study: planning, study design, and methodology." Food and Nutrition Bulletin, 25(I supplI), SI5-S26.

Dykstra, P.A \& Poortman, A.R. 20I0. "Economic Resources and Remaining Single: Trends Over Time." European Sociological Review 26, (3): 277-290. https://doi.org// 0.1093/esr/jcp02 I

Ejaz, M.S \& Latif, N. 2010. "Stunting and micronutrient deficiencies in malnourished children.” JPMA, 60, (543)

Faruque, A.S.G., et al. 2008. "Nutrition: Basis for Healthy Children and Mothers in Bangladesh." Journal of Health, Population, and Nutrition 26, (3): 325-339.

Fernald, L.C \& Neufeld, L.M. 2007. "Overweight with concurrent stunting in very young children from rural Mexico: prevalence and associated factors." European journal of clinical nutrition 6I(5): 623-632.

Habaasa, G. 20I5. "An investigation on factors associated with malnutrition among underfive children in Nakaseke and Nakasongola districts, Uganda." BMC pediatrics, 15, (I): I 34.

Heiland, F \& Liu, S.H. 2006. "Family structure and wellbeing of out-of-wedlock children: The significance of the biological parents' relationship." Demographic Research 15: 6I-104. https://doi.org/I0.1 I86/I47|-2458-I4-I I45

Ikamari, L. 2005. "The effect of education on the timing of marriage in Kenya." Demographic Research, 12: I-28. https://doi.org// 0.4054/DemRes.2005.12.I

Madhavan, S \& Townsend, N. 2007. "The social context of children's nutritional status in rural South Africa." Scandinavian Journal of Public Health 35, (69): 107-II 7.

Menard, S. 2002. Applied Logistic Regression Analysis. SAGE.

Müller, O \& Krawinkel, M. 2005. "Malnutrition and health in developing countries." Canadian

Schmeer, K.K., 2012. Family structure and obesity in early childhood. Social Science Research, 4I, (4): 820-832.

Takyi, B.K \& Gyimah, S.O. 2007. "Matrilineal Family Ties and Marital Dissolution in Ghana." Journal of Family Issues 28, (5): 682-705. https://doi.org/ I0. I 177/0 I925 I 3X07028005040 I

Ubesie, A.C., Ibeziako, N.S., Ndiokwelu, C.I., Uzoka, C.M., \& Nwafor, C.A. 2012. "Under-five protein energy malnutrition admitted at the University of 
in Nigeria teaching hospital, Enugu: a 10 year retrospective review. Nutrition Journal, I I (I), I.

UNICEF, WHO, World Bank, UN-DESA Population Division. (20|3). Levels and trends in child mortality. Retrieved from

http://www.who.int/maternal_child_adolescent/d ocuments/levels_trends_child_mortality_20 I3.pdf ?ua $=$ I

\footnotetext{
${ }^{a}$ Dr Jeremy Gumbo passed on, on May 3, 2017 just before the publication of this article. Before his death, Jeremy contributed significantly to the conceptualisation, analysis and writing of this manuscript. Both the first draft and the revised manuscript were approved by the deceased before his death.
}

World Health Organization. (2006). Neonatal and Perinatal Mortality: Country, Regional, and Global Estimates. Retrieved from http://whqlibdoc.who.int/publications/2006/924I5 63206_eng.pdf

Yount, K. M., \& Carrera, J. S. (2006). Domestic violence against married women in Cambodia. Social Forces, 85(I),355-38. 